\title{
Comparison of Microbially Induced Healing Solutions for Crack Repairs of Cement-Based Infrastructure
}

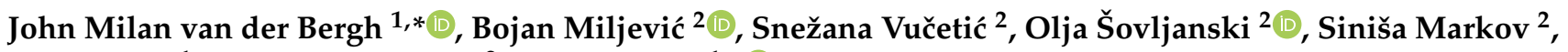 \\ Mike Riley ${ }^{1}$, Jonjaua Ranogajec ${ }^{2}$ and Ana Bras ${ }^{1, *(D)}$ \\ 1 Built Environment and Sustainable Technologies (BEST) Research Institute, Liverpool John Moores University, \\ Liverpool L3 2ET, UK; M.L.Riley@ljmu.ac.uk \\ 2 Faculty of Technology, University of Novi Sad, 21000 Novi Sad, Serbia; miljevic@uns.ac.rs (B.M.); \\ snezanap@uns.ac.rs (S.V.); oljasovljanski@uns.ac.rs (O.Š.); sinisam@tf.uns.ac.rs (S.M.); janjar@uns.ac.rs (J.R.) \\ * Correspondence: J.M.vanderBergh@2019.ljmu.ac.uk (J.M.v.d.B.); a.m.armadabras@ljmu.ac.uk (A.B.)
}

\section{check for}

updates

Citation: van der Bergh, J.M.; Miljević, B.; Vučetić, S.; Šovljanski, O.; Markov, S.; Riley, M.; Ranogajec, J.; Bras, A. Comparison of Microbially Induced Healing Solutions for Crack Repairs of Cement-Based Infrastructure. Sustainability 2021, 13, 4287. https://doi.org/10.3390/ su13084287

Academic Editors: Ana Bras and Antonio Conforti

Received: 28 February 2021

Accepted: 9 April 2021

Published: 12 April 2021

Publisher's Note: MDPI stays neutral with regard to jurisdictional claims in published maps and institutional affiliations.

Copyright: (c) 2021 by the authors. Licensee MDPI, Basel, Switzerland. This article is an open access article distributed under the terms and conditions of the Creative Commons Attribution (CC BY) license (https:// creativecommons.org/licenses/by/ $4.0 /)$.

\begin{abstract}
Reinforced concrete crack repair and maintenance costs are around $84 \%$ to $125 \%$ higher than construction costs, which emphasises the need to increase the infrastructure service life. Prolongation of the designed service life of concrete structures can have significant economic and ecological benefits by minimising the maintenance actions and related increase of carbon and energy expenditure, making it more sustainable. Different mechanisms such as diffusion, permeation and capillary action are responsible for the transport of fluids inside the concrete, which can impact on the structure service life. This paper presents data on microbially induced repair and self-healing solutions for cementitious materials available in the contemporary literature and compares results of compressive strength test and capillary water absorption test, which are relevant to their sealing and mechanical characteristics. The results of the repair and self-healing solutions (relative to unassisted recovery processes) were "normalized." Externally applied bacteria-based solutions can improve the compressive strength of cementitious materials from $13 \%$ to $27 \%$. The internal solution based solely on bacterial suspension had 19\% improvement efficacy. Results also show that "hybrid" solutions, based on both bio-based and non-bio-based components, whether externally or internally applied, have the potential for best repair results, synergistically combining their benefits.
\end{abstract}

Keywords: self-healing; MICP; concrete repair; external healing; service life; crack repair; compressive strength recovery improvement; capillary water absorption reduction

\section{Introduction}

Concrete structures and buildings compose the vast majority of constructions currently in service. Although concrete presents arguably the most versatile material for building, it is also very prone to degradation, especially to cracking due to weathering, thermal stresses, drying shrinkage, plastic shrinkage, internal forces due to loading and incompatibility of the material within the matrix [1]. Formed cracks not only deteriorate the structural integrity of concrete but also allow water and chemicals to penetrate to embedded steel reinforcement, which further negatively impact the structure. Even though concrete has relatively low production energy consumption per tonne, the total annual production of almost 10 billion tonnes makes it the material with the largest annual production energy consumption in the world (around 11 billion GJ, Figure 1) [2]. This high amount of production energy carries inevitably a high burden of carbon emissions totalling about 2.8 billion tonnes per year or $8 \%$ of the global total [3].

Additionally, it is estimated that concrete crack repair and maintenance costs are around $84 \%$ to $125 \%$ higher than construction costs, per $\mathrm{m}^{3}$ [4]. It can therefore be seen that the prolongation of designed service life of concrete structures can have significant economic and ecological benefits by minimising the maintenance actions and related increase of carbon and energy expenditure. 


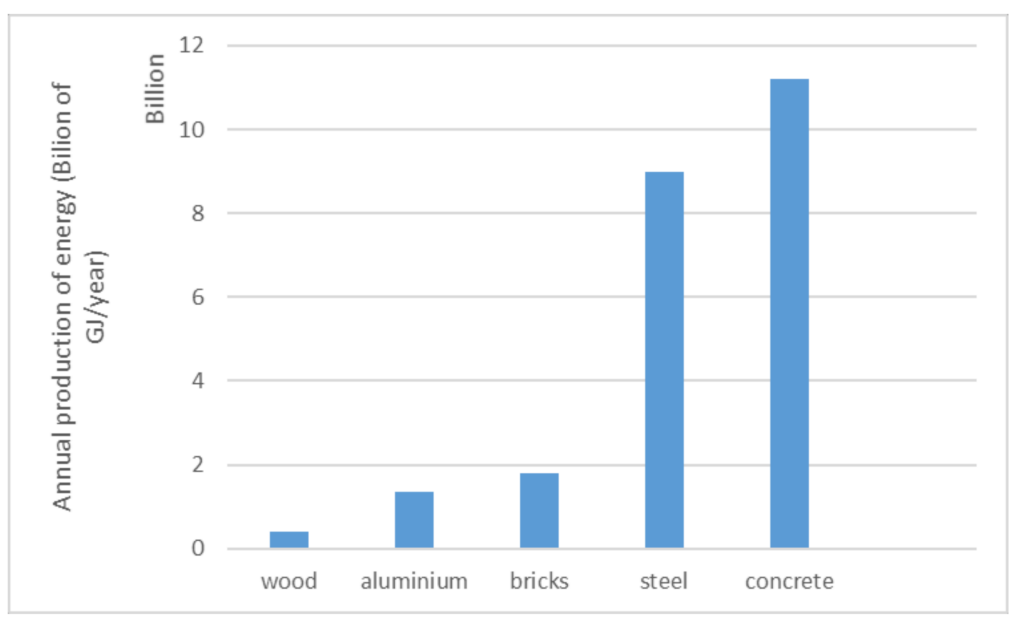

Figure 1. Annual production energy (in GJ/year) of selected building materials (data source: [2]).

In order to assess the sustainability of a structure, apart from the obvious environmental and economic impacts due to construction, the costs of maintenance during its service life need to be included as well [5]. Evidently, the cracks affect the long-term durability of the concrete, which makes the crack control a fundamental matter in the design phase and service life of a concrete structure. Durability, and therefore sustainability, would be increased if inherently present cracks in concrete could be (self-)healed, as the material would have longer service life [6]. As cracks provide additional pathways for water and waterborne ions to penetrate the material, mass exchange and transfer play a vital role in deterioration processes. Different mechanisms such as diffusion, permeation and capillary action are responsible for the transport of fluids inside concrete [7]. Without going into details about the fractal properties of cracks, the geometrical shape of crack can be defined as two rough fractured surfaces and the space limited by them, filled by one or more fluid phases, most commonly air and water.

Crack width presents the primary parameter for assessment and limiting the impact of cracking on concrete durability according to most design standards. The critical value of conventional crack width limit appears to be around $200 \mu \mathrm{m}$ for severe and $300 \mu \mathrm{m}$ for moderate exposure [8]. In other words, stricter limits should be enforced in case of severe environments, while more lenient limits are tolerated for moderate exposure. It should be noted, however, that the American codes tend to give precedence to a general good practice approach with steel stress control [9], rather than impose numerical crack width limit values, as European/British [8,10], Chinese and Japanese standards do. Additionally, crack control for durability, apart from loading cracks, must include thermal, plastic and autogenous shrinkage cracks, which affect the bulk material and have a profound impact on long-term durability [11]. One should also bear in mind that the real geometry of cracks is far more complex, with several other parameters that define the crack apart from the mere width: crack tortuosity, crack roughness, and crack depth (length perpendicular to the surface).

According to the Tuuti's model [12], the service life of a reinforced concrete structure has two main stages: the initiation and the propagation stages (Figure 2). The initiation stage is defined as time required for the naturally present passive layer, which protects the reinforcement bar (rebar), to be removed (usually by chloride action — chloride ions are transported through cracks in the concrete cover and come directly in contact with steel). Propagation period starts after the initiation period, and it is defined as the time period during which the rebar is corroding. Its cross section reduces due to chemical reactions of iron oxidation, which leads to formation of products on the surface of the bars. This produces tensile stresses, which lead to further cracking, spalling and collapse. 


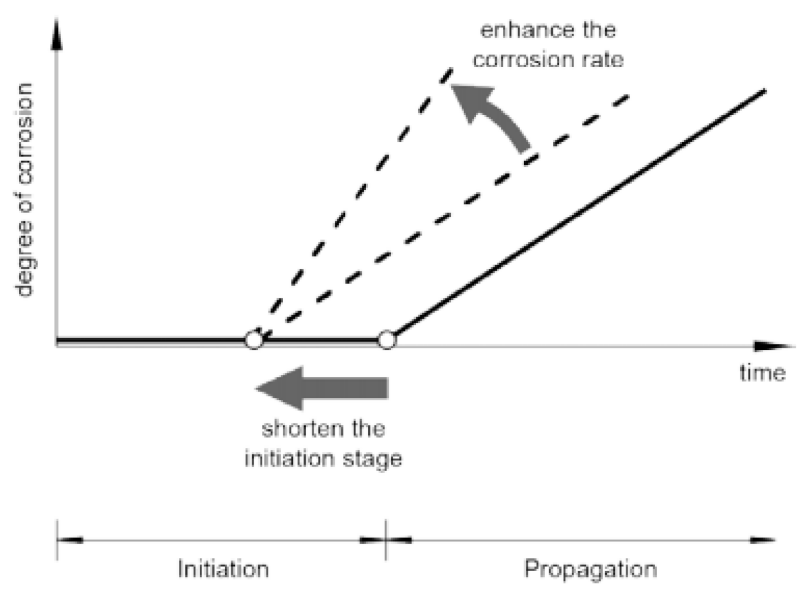

Figure 2. Schematic display of possible effects of cracks on the service life of reinforced concrete structures using Tuuti's service life model [13].

There are still some open questions about the influence of cracks on the durability of concrete, especially on the corrosion of the reinforcing steel bars. Some of them are: how much do cracks in concrete shorten the initiation time of corrosion processes; how much do cracks affect the propagation stage of corrosion (i.e., enhance the corrosion rate), Figure 2; and finally, how much can the presence of cracks shorten the service life of a structure [14]?

\subsection{Terminology of (Self-)Healing and Repair in the Context of Available Options for Service Life Increase}

In order to better understand the available options for increasing the service life and durability of concrete building and structures, a good start would be to define the various terms used in this field. The same terms in literature are used to describe different mechanisms, and consequential miscommunication can hinder their study and comparison. For this purpose, the most important terms to define are self-healing, self-sealing, repairing, self-tightening, and some other terms more closely defining the processes that are occurring.

Self-healing, according to Zhang et al. (2020), refers essentially to processes in the material (concrete) that automatically repair small cracks, "without any external diagnosis or human intervention" [2]. This definition would therefore render all externally added healing agents as non-self-healing, although they may base their activity on similar or the same mechanisms as self-healing (e.g., inducing calcium-carbonate precipitation in cracks). This is similar to the stance presented in the review article by De Belie et al. (2018), where the crack-treating techniques are categorised as "passive" and "active". The latter consist of adding the healing agents in the construction stage, their being the only ones considered to be self-healing [15]. The choice of terms "active" and "passive" is particularly interesting and might seem even counterintuitive, since these authors labelled the manually applied solutions as "passive" (although deliberate action is necessary in order to repair the cracks), and on the other hand the "active" solution acts on its own (which might be considered passive) when certain conditions are met. It can be argued, however, that the logic behind naming these techniques as active in this case represents the intent of the engineers to actively (and even pre-emptively) repair the cracks as soon as they are formed, rather than to passively "wait" for them to appear before proceeding with the repair. Other authors allow "material ... little external help to regain its desirable mechanical properties" [16] in their definition of self-healing, but do not define the exact extent of this help.

Ultimately, it could be argued that self-healing in the strictest sense encompasses only autogenous self-healing processes, which rely on conventional components of the cementitious matrix. However, the majority of researchers consider that adding various tailored admixtures to cement matrix formulations in order to induce self-healing processes satisfies the definition of self-healing [15]. RILEM (the International Union of Laboratories and Experts in Construction Materials, Systems and Structures) has proposed clearer definitions 
of self-healing that, according to this technical body, include "any process by the material itself involving the recovery and hence improvement of a performance after an earlier action that had reduced the performance of the material." The well-known terms autogenous self-healing and autonomous self-healing are also defined: autogenous (autogenic) includes processes based on components that would be present in the material in any case (own generic materials), and autonomous (autonomic) relies on components specifically added to the material that would otherwise not be present (engineered additions). "Stimulated" autogenous healing is another term used by some authors, where certain commonly used admixtures such as fly-ash or blast furnace slag have been shown to induce self-healing processes [15]. Whether this classifies as autonomous or autogenous self-healing could be subject of debate, depending mainly on the intention of the engineers designing the mix-if the main purpose of these additions was to create self-healing material, then they would fall out of RILEM's autogenous self-healing definition (since they would not have been normally present in the mix otherwise). This raises a question of up-to-dateness of this RILEM definition in the future, as with time the concrete and cement mortar technology will inevitably evolve to routinely include novel additions that will eventually become generic material themselves, and therefore potentially "move" self-healing solutions from autonomous to autogenic class.

Self-sealing, compared to self-healing, has been defined as encompassing processes that lead to leaking cracks being sealed without recovering strength of the material [17]. This creates a certain ambiguity in the field of self-healing materials because self-sealing improves the performance of the material after its earlier reduction, and therefore satisfies the RILEM definition of self-healing. It is useful, though, to differentiate between these two terms as this gives more clear and immediate information about the type of performance improved (mechanical and/or permeation). Hearn (1998) gave an overview of the selfsealing effect (SSE) and noted that this term had been used to describe continued hydration and autogenous healing processes as well. In summary, this author concludes that the main difference between these three phenomena is the conditions under which they occur: SSE occurs in dry conditions after extensive microcracking, continuous hydration needs moist environment and non-hydrated components in the material, and autogenous healing takes place predominantly in cracks with water flow and exposure to atmosphere [18]. It can be seen that different authors emphasise different aspects of the phenomena when they define them-in the first instance, from the beginning of the paragraph the emphasis was put on the performance description (sealing crack without recovering strength), and in the latter on the mechanism and conditions under which it occurs. The term self-tightening is described as one of the self-healing mechanisms that rely on particles from crack faces or fluid that flows through the crack to block it. It should be noted that it has on occasion been used interchangeably with the term self-sealing [19].

\subsection{Different Approaches to (Self-)Healing and Repair with Focus on Bacteria-Based Solutions}

Self-healing solutions include a wide spectrum of engineered or tailored additions. Crystalline admixtures (CAs) belong to a special class of permeability reducing admixtures capable of acting under hydrostatic pressure [15]. Commonly used crystalline admixtures promote calcium-silicate crystallisation by reacting with $\mathrm{CaO} \cdot \mathrm{SiO}_{2}$, which can have a positive impact on crack closure. Ion chelator-based crystalline admixture facilitates the $\mathrm{Ca}^{2+}$ diffusion from the cement matrix to the crack, where the $\mathrm{Ca}^{2+}$ reacts with $\mathrm{SiO}_{3}{ }^{2-}$ and $\mathrm{CO}_{3}{ }^{2-}$ forming products that fill the crack [20]. Granulated blast furnace slag (GBFS) has been extensively used as an admixture due to its pozzolanic activity, which prompted researchers to study the influence of CA on GBFS mortar. This proved to have better self-healing abilities than plain cement mortar with CA [21]. Encapsulation is the method of choice for some researchers as this solution has a more targeted approach to damaged (cracked) areas. The basic principle is that the capsules are the carriers of a healing agent that breaks upon the formation of the crack inside the matrix, releasing the agent and thus 
healing the crack. This approach was employed by Sidiq et al. (2020), who used silica-based microcapsules [4] developed specifically for this purpose.

A novel class of material that is gaining popularity among researchers in the field of repair and self-healing of concrete and cementitious materials is bacteria-based repair agents, which, according to some authors, represent the frontier in the field of material science [2]. Bacterial concrete has also shown the potential to become an effective response to growing sustainability requests [22]. The basic principle of these repair techniques (Figure 3) is to utilise the ability of some bacterial species to induce precipitation of calciumcarbonate inside the cementitious matrix. In this way, cracks in concrete can be filled with calcium-carbonate, which, as a consequence, improves water impermeability and mechanical characteristics of concrete.

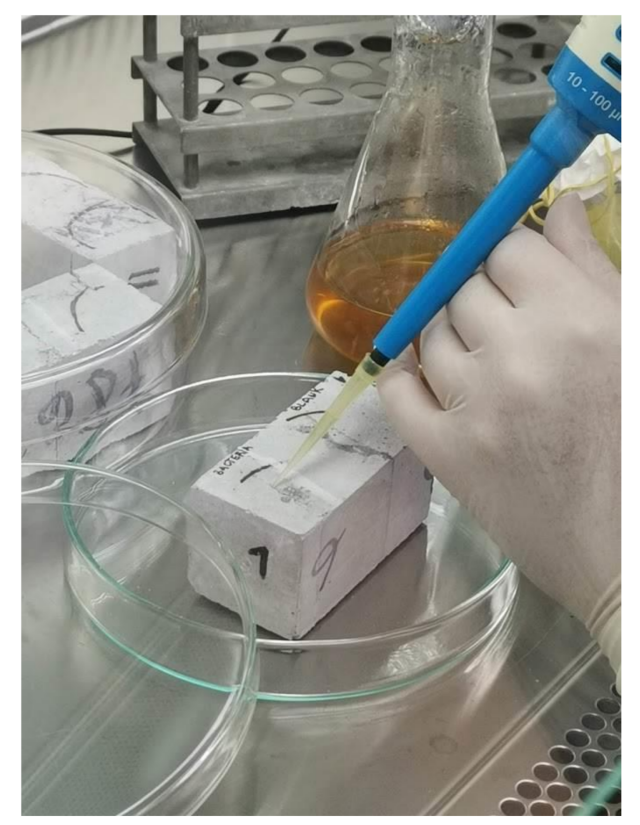

Figure 3. Application of bacteria-based repair agent onto an artificially generated crack on cement mortar beam (authors' image).

The bacteria used for application in a concrete environment need to be alkalophilic or alkalitolerant and, ideally, spore-forming, in order to survive unfavourable conditions that may occur during the service life of the structure. The healing processes based on bacterial activity have been variously described as bio-stimulation, bio-augmentation [23], bio-activation [24], bio-induction, and (bio-)remediation [25]. Bio-stimulation is in fact the process of adjustment of environmental conditions such as nutrients, substrate, water, etc., to enhance favourable metabolic processes of naturally present microflora. Bioaugmentation, on the other hand, relies on introduction of previously absent bacteria on the material to be treated, usually employing specialised strains with selected bestsuited characteristics [26], although locally isolated strains have also been studied in this regard $[23,27,28]$. (Bio-)activation is a somewhat ambiguous term used to describe both the bio-augmentation approach [24] and the bio-stimulation one [29,30], and it would be beneficial to consider standardising this term for future reference to avoid possible misunderstandings. Bio-induction has been used synonymously with the term microbiologically induced calcium-carbonate precipitation (MICP), coined by Stocks-Fischer et al. (1999) [31], employing various types of bacteria that can be classified by their metabolism into three main groups: ureolytic, denitrifying and aerobic heterotrophic. Although in the literature the letter $\mathrm{C}$ in the MICP abbreviation has also been used to denote "calcite" instead of "calcium-carbonate" $\left(\mathrm{CaCO}_{3}\right)$ [32-34], the latter term should be preferred as the carbonate precipitate is not always necessarily in calcite form but can also take vaterite $[35,36]$ or aragonite [37] forms of $\mathrm{CaCO}_{3}$. Side products of metabolism of the aforementioned bacteria 
are carbonate $\left(\mathrm{CO}_{3}{ }^{2-}\right)$ ions, which afterwards react with available calcium $\left(\mathrm{Ca}^{2+}\right)$ ions from the cementitious matrix to form $\mathrm{CaCO}_{3}$ precipitation, if parameters of the environment are adequate. Ureolytic bacteria produce the enzyme urease to catalyse the hydrolysis of urea $\left(\mathrm{CO}\left(\mathrm{NH}_{2}\right)_{2}\right)$ to ammonia $\left(\mathrm{NH}_{4}{ }^{+}\right)$and carbonate ions, which are the end products of the energy-generating chemical reactions used for their life processes (Equations (1) and (2)).

$$
\begin{gathered}
\mathrm{CO}\left(\mathrm{NH}_{2}\right)_{2}+2 \mathrm{H}_{2} \mathrm{O} \stackrel{\text { bacterial urease }}{\rightarrow} 2 \mathrm{NH}_{4}^{+}+\mathrm{CO}_{3}^{2-}, \\
\mathrm{CO}_{3}^{2-}+\mathrm{Ca}^{2+} \rightarrow \mathrm{CaCO}_{3} .
\end{gathered}
$$

The most commonly used ureolytic bacteria for MICP are Sporosarcina pasteurii, Sporosarcina ureae, Bacillus megaterium and Bacillus sphaericus [15,38]. As these bacteria are aerobic, i.e., they require oxygen for their metabolic processes, they are believed to be more suitable for surface crack treatment, where oxygen is abundant. For deeper cracks where oxygen might be scarce it would be wise to use denitrifying bacteria, which in anoxic conditions use nitrate ions $\left(\mathrm{NO}_{3}{ }^{-}\right)$in their metabolic processes (Equations (3) and (4)):

$$
\begin{gathered}
2 \mathrm{NO}_{3}^{-}+5 \mathrm{HCOO}^{-} \rightarrow \mathrm{N}_{2}+3 \mathrm{HCO}_{3}^{-}+\mathrm{H}_{2} \mathrm{O}+2 \mathrm{CO}_{3}^{2-} \\
\mathrm{CO}_{3}^{2-}+\mathrm{Ca}^{2+} \rightarrow \mathrm{CaCO}_{3} .
\end{gathered}
$$

Aerobic heterotrophic bacteria can consume calcium salts of organic acids and produce carbonate ions, which then form calcium-carbonate, according to Equations (2) and (4).

Finally, the bacterial cells themselves can act as nucleation sites, since the negatively charged bacterial cell walls attract positively charged calcium ions and these consequently induce a chemical reaction with carbonate ions to produce calcium-carbonate (Figure 4).
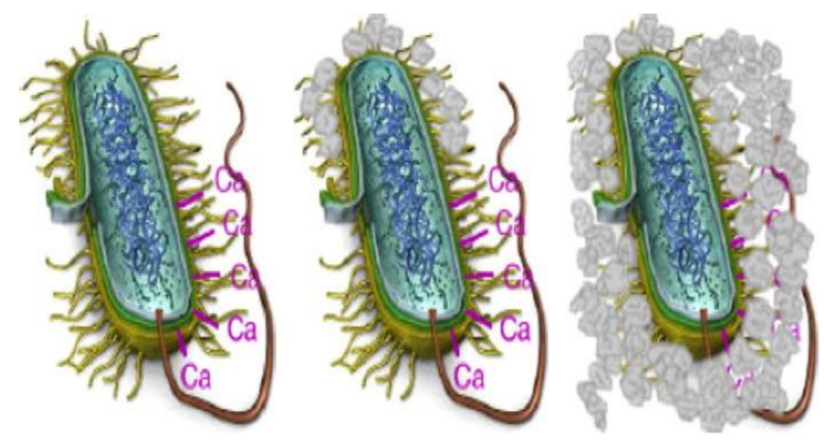

Figure 4. Schematic representation of bacterial cell as nucleation sites for microbially induced calcium-carbonate precipitation (MICP) [39].

Currently, the majority of research has been done on internal self-healing solutions $[1,2,15,40,41]$, which presume adding the self-healing agents to the mix before the service life of the structure has even begun (building phase), also known as the "active" techniques. As mortar and concrete present a less than ideal substrate for bacterial cells because of high $\mathrm{pH}$ values and vigorous mixing processes, various additional components are added to support them and help them survive harsh conditions. Strategies for protection of bacteria are based on microencapsulation, impregnation in various carriers, and encapsulation in hydrogels [15]. Some authors such as Gupta et al. (2018) even employed a multifunctional approach studying biochar as a potential carrier for bacteria, and also a superabsorbent polymer to ensure the bacteria are well supplied with moisture, and polypropylene microfibres to enhance fracture toughness of the bulk material [42].

Although the "active" approach has many benefits that express themselves in the future service life of constructions, it cannot address the problems that the currently used structures (without such self-healing materials) face as regards their deterioration. There have been several extensive review papers written on internal self-healing approaches, but only a few papers have considered externally applied bacteria-based agents or materials 
for concrete repair [33,43-46], which emphasises the fact that the research in this field is still in its early stages. Another option for utilising MICP is to treat already formed cracks with a bio-agent containing suitable bacteria and nutrients. This was exactly the case in research conducted by van der Bergh et al. (2020) [46] and Jongvivatsakul et al. (2019) [43]. The basic principle is to drop the bacteria-based bio-agent onto/into cracks already present in the substrate material. The bio-agent enters the cracks after which the bacteria contained in the bio-agent solution induce calcium-carbonate precipitation using calcium and carbonate ions from their surroundings (cementitious matrix). Additionally, other components such as sand [47] might be part of the repair agent, giving the substrate better mechanical characteristics due to bacteria-mediated consolidation processes.

It is important to define the types of technique used in these cases as they represent novel ways for crack treatment. First of all-is it self-healing at all? According to RILEM, any technique requiring the material to be added or replaced externally cannot be considered self-healing, but rather be called repair. Since the bio-agent is added in this way from the outside on already developed cracks, strictly speaking, the aforementioned authors did not engage in self-healing by RILEM's interpretation. However, the processes that took place inside the cracks and the material were based on inducing the naturally present components of the cementitious matrix to react and seal and/or heal the cracks. This is very different from, e.g., polymeric sealant or penetrant solutions that use their own volume of (polymeric) material to block the pores and cracks. In case of a bio-agent based on bacteria and nutrients, the agent per se does not act as sealant, but induces the bulk material (concrete or cementitious matrix) to seal/heal itself. It can be, therefore, argued that this novel repair technique employs self-healing/self-sealing processes, and that RILEM at the time they were drawing up the definitions of self-healing had not yet encountered this specific technique. Thus, it is proposed that these novel techniques be named external healing, in order to describe them as externally applied (as opposed to internally) and as healing (as they employ similar or the same mechanisms as self-healing materials, but they do not fall into RILEM's self-healing definition).

Surface repair of structures based on self-healing of concrete materials presents a promising technique for maintenance of buildings in service and can potentially be a costeffective way of prolonging their service life. Most commonly used application techniques for external repair are immersion, spraying, dropping and brushing [48]. Immersion technique is usually only applicable to laboratory testing, since it is normally not practical to immerse large structures or structural elements in repair agents. Nevertheless, this technique can be a good starting point for the development of self-healing repair agents, which can then be optimised for another more adequate in situ application technique, such as brushing, spraying or dropping.

The approaches to repair can be classified according to standard EN 1504 as impregnation, sealing and coatings [49]. Materials used for these procedures can be classified as inorganic and organic (which include bio-based) materials. Inorganic materials used for repair are usually based on cement grout with specific admixture components that improve the workability and other characteristics of the material, so they better fit the purpose. One of the especially important parameters is the ability of the material to be injected in very narrow spaces and cracks. This is achieved by using components with extra fine particles such as fly ash, metakaolin, microsilica and granulated blast furnace slag [50]. The main drawback of these kinds of materials, though, is their inability to fill in microcracks (smaller than $500 \mu \mathrm{m}$ ) [51], but their better compatibility with inorganic substrate means that they are generally more durable than polymeric materials used for repair.

Organic products (excluding bio-based) used for concrete repair and protection are polymeric materials based on polyurethanes [52], epoxy resins [53], acrylics [54], acrylamides [55], silanes, siloxanes [56] and other polymers. Generally speaking, these materials possess very good sealing characteristics, but their durability is not optimal because of their incompatibility with the inorganic substrate, which leads to subpar adhesion at sealant-substrate interface and subsequent detachment. Furthermore, polymeric materials 
being organic-based can be prone to microbiological attack. Also, there is concern about them not being environmentally friendly.

\section{Comparison of Efficacy of Selected Healing Solutions}

The evaluation techniques for crack repairs in concrete and cement mortar rely on visual and chemical-mineralogical analyses, sealing capabilities tests and mechanical properties tests. There is a wide variety of available methods and techniques, which can be divided into four main categories: crack closure investigation, recovery of durability properties, recovery of mechanical properties, and, finally, healing product analysis [57]. The spectrum of available techniques and methods is indeed wide, but only a relatively small number of them are widely and routinely used. These are the methods commonly used in the construction materials industry, with certain modifications that allow the investigators to get more specific information on their particular product or application method. The most commonly used techniques are scanning electron microscopy and light microscopy for viewing and measuring of the cracks, capillary absorption test, water permeability tests, 3-point bending test, compressive strength test and tensile strength test.

In order to compare the results of our newly designed bio-based repair agent for cracks in cement mortar [46], a literature study of other repair agents was conducted and several other solutions (that were tested using the same or similar methodology) were chosen for a comparative overview. Although there are differences in methodology of the repair agent application and measurements in the available literature, this comparison should be taken as a generalised overview of repair efficacy of certain solutions. In this sense, it is proposed that the efficacy of the repair agent be viewed relative to unassisted recovery processes. In other words, the objective is to find out how much the used repair agent increases the performance of a chosen substrate, compared to leaving the substrate in the same conditions but without actively performing any repair on it. The testing methods chosen in this study of comparison were compressive strength testing and capillary water absorption. These methods were chosen as they intuitively indicated different aspects of material healing, i.e., the recovery of mechanical properties (determined by the compressive strength testing) and sealing characteristics (determined by the capillary water absorption).

\subsection{Compressive Strength Recovery Improvement}

De Nardi et al. (2017) described a methodology for evaluation of self-healing through measurement of strength gain, defined as the difference of compressive strengths obtained by testing pre-cracked samples at the start of the experiment and after the curing (healing) period [58]. This is a solid way to determine the efficacy of healing, though it is limited to the same experimental conditions.

Compressive strength recovery improvement (CSRI) is an attempt to compare the results of data obtained by different authors using various methodologies of experiments. It basically shows the efficacy of the employed agent and application method in comparison to unassisted recovery processes naturally occurring in the material (relative increase of recovery), as shown in Equation (5):

$$
\mathrm{CSRI}=\frac{\mathrm{CSV}_{\text {s.a.t }}-\mathrm{CSV}_{\text {b.a.u.h }}}{\mathrm{CSV}_{\text {b.und }}} \cdot 100 \%
$$

where

CSRI is compressive strength recovery improvement (\%);

$\mathrm{CSV}_{\text {s.a.t }}$ is compressive strength value of the sample after treatment (with external agent) or after curing (being previously pre-cracked, in the case of internal agents);

$\mathrm{CSV}_{\text {b.a.u.h }}$ is compressive strength value of plain mix (blank) after the period of unassisted healing - in case of external agents these are the non-treated samples, and in the case of internal agents these are the plain mix (blank) samples;

$\mathrm{CSV}_{\text {b.und }}$ is the reference compressive strength value, i.e., the compressive strength value of non-treated undamaged plain mix (blank) sample. 
Figure 5 shows a comparison between some results of self-healing and crack repairing solutions in regard to their compressive strength recovery ability, found in contemporary literature (the majority of papers were published in 2019 or 2020, Table 1). The authors of this study chose to present the comparison of both internal ("active") and external ("passive") types of repair solutions, as well as bio-based (bacterial) vs. non-bio-based (non-bacterial) solutions vs. "hybrid" (employing bio- and non-bio-based components), since similar healing processes are thought to be responsible for strength gain in all cases.

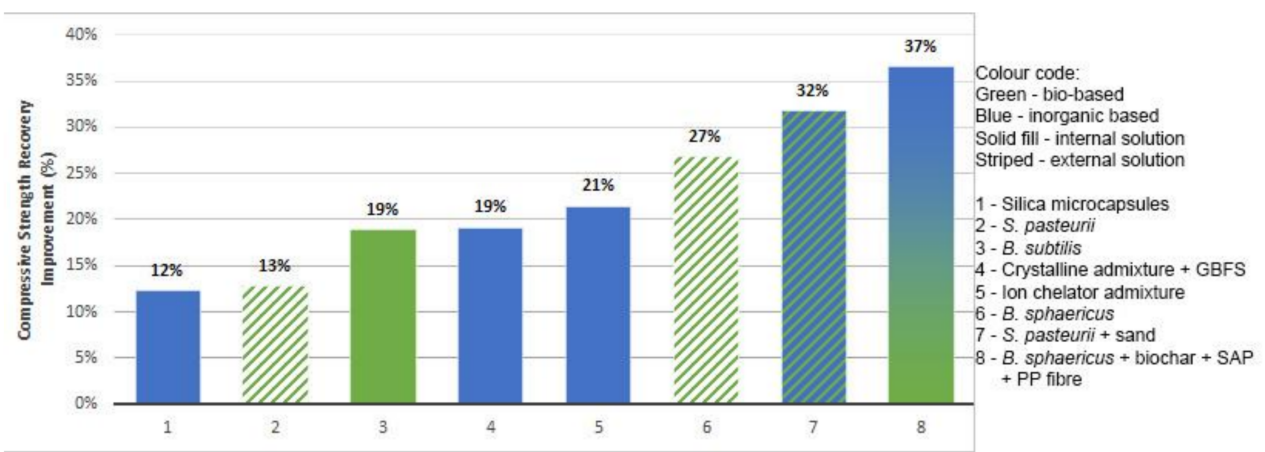

Figure 5. Improvement of compressive strength recovery of certain self-healing and crack repair solutions relative to unassisted recovery processes: 1 - [4] (blank is the mix with less admixture); 2-[46]; 3-[59]; 4-[21]; 5-[20]; 6-[43]; 7-[47]; 8-[42].

Table 1. Overview of the healing solutions used for the comparison study.

\begin{tabular}{|c|c|c|c|c|c|}
\hline $\begin{array}{l}\text { No. in } \\
\text { Figure } 5\end{array}$ & Authors & $\begin{array}{l}\text { Type of } \\
\text { Solution }\end{array}$ & Solution Based on & Curing Time & $\begin{array}{l}\text { Pre-Loading Force } \\
\text { (of max.) }\end{array}$ \\
\hline 1 & Sidiq et al. (2020) [4] & Internal & $\begin{array}{l}\text { Sodium silica } \\
\text { microcapsules }\end{array}$ & 28 days & $70 \%$ \\
\hline 2 & Van der Bergh et al. (2020) [46] & External & Sporosarcina pasteurii & 28 days & To failure \\
\hline 3 & Khushnood et al. (2020) [59] & Internal & Bacillus subtilis & 28 days & $85 \%$ \\
\hline 4 & Li et al. (2020) [21] & Internal & $\begin{array}{c}\text { Penetron Admix }{ }^{\circledR} \\
\text { crystalline admixture + } \\
\text { granulated blast furnace } \\
\text { slag }\end{array}$ & 28 days & To failure \\
\hline 5 & Wang et al. (2020) [20] & Internal & $\begin{array}{l}\text { Ion chelator crystalline } \\
\text { admixture }\end{array}$ & 21 days & $60 \%$ \\
\hline 6 & Jongvivatsakul et al. (2019) [43] & External & Bacillus sphaericus & 20 days & $\mathrm{N} / \mathrm{a}$ \\
\hline 7 & Abo-El-Enein et al. (2012) [47] & External & $\begin{array}{c}\text { Sporosarcina pasteurii }+ \\
\text { sand }\end{array}$ & 28 days & $\mathrm{N} / \mathrm{a}$ \\
\hline 8 & Gupta et al. (2018) [42] & Internal & $\begin{array}{c}\text { Bacillus sphaericus }+ \\
\text { biochar }+ \\
\text { superabsorbent polymer } \\
+ \text { polypropylene fibres }\end{array}$ & 21 days & $50 \%$ \\
\hline
\end{tabular}

It can be seen that externally applied bacteria-based solutions improved the compressive strength of cementitious materials from 13 to $27 \%$, not counting the solution that also incorporated non-bio-based components (sand), which improved the strength up to $32 \%$. This was an important finding as it showed that bacterial solutions can in fact not only seal, but also heal material, i.e., recover its mechanical properties instead of only mitigating the propagation of water. The observed strength improvement could be explained by the chemical bonding between the calcium-carbonate from bacteria metabolism and consolidation promoted by the sand particles acting as a filler of the cracks. Concomitantly, sand might 
have a positive influence as a subtract for biofilms growing, enabling a better behaviour at a macro-scale.

Different internal non-bio-based solutions (added at the mixing phase) had the potential to improve the compression strength properties between 12 and $21 \%$, while the internal solution based solely on bacterial suspension had 19\% improvement efficacy. However, the best results were obtained by combining the non-bio-based and bio-based components at the mixing phase- $37 \%$, albeit these agents are more complex and difficult for eventual real-life manufacture and application. Interestingly, both internal and external solutions based on combined non-bio-based and bio-based components (solutions 7 and 8, Figure 4 and Table 1) showed the best results regarding the healing potential. This showed that the combined "synergistic" approach could be a promising path in further research efforts.

\subsection{Comparison of Required Volume of Repair Solutions}

Additionally, the bio-agent used in our preliminary study of external healing solution [46] was analysed.

The compressive strength results (Figure 6) showed that there was a strength increase of $7.5 \mathrm{MPa}\left(750\right.$ tonnes more per $\mathrm{m}^{2}$ ) if the mortar cracks were repaired with $200 \mu \mathrm{L}$ of external healing solution per $4 \mathrm{~cm}$ of crack length $(4 \mathrm{~cm}$ is one of the dimensions of the standard $4 \mathrm{~cm} \times 4 \mathrm{~cm} \times 16 \mathrm{~cm}$ EN 196-1 test mortar beams used in the study). Assuming that a significant crack width of at least $0.3 \mathrm{~mm}$ is a cause for concern, this means that in order to heal a crack that is $1 \mathrm{~m}$ long, $0.04 \mathrm{~m}$ deep, and $0.0003 \mathrm{~m}$ wide $-5 \mathrm{~mL}$ of bioproduct is required. The results also showed that the strength increase with bio-agent was around $20 \%$ and the scattering was lower for the bio-based mortars.

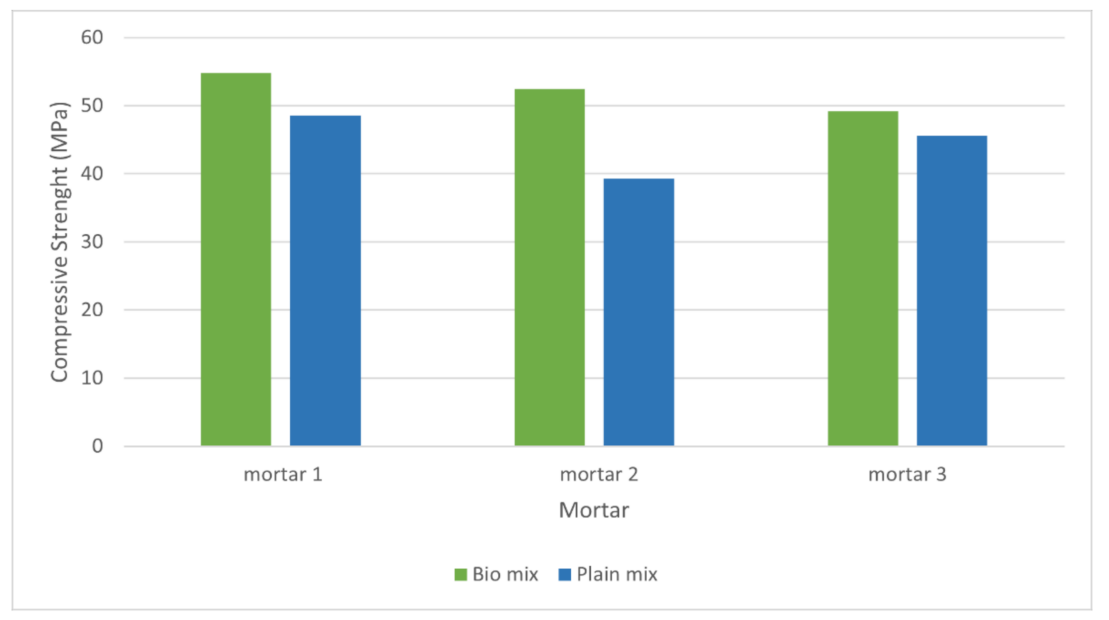

Figure 6. Compressive strength of untreated cement mortar beams (plain mix) and those treated with bio-agent repair solution (bio-mix) by van der Bergh et al. (2020).

Therefore, it would be interesting to compare the agent consumption between different external repair techniques in order to further assess their efficacy. Using the data published by Jongvivatsakul et al. [43] (here named as J solution) and extrapolating it to a crack of equal size $\left(1 \times 0.04 \times 0.0003 \mathrm{~m}^{3}\right)$, the calculated required solution volume for repair is $203.12 \mathrm{~mL}$. It should be noted that this volume was applied every day over the course of 20 days, so the total repair solution volume needed was $4062.5 \mathrm{~mL}$, which is over 800 times more than the $5 \mathrm{~mL}$ of bio-solution required in the preliminary study by van der Bergh et al. [46] (here named as VDB solution). It could be further argued that the efficacy of the latter solution is about 400 times larger (given that the improvement amounts of compressive strengths, Figure 4 , are $27 \%$ and $13 \%$, respectively), although this would be somewhat oversimplified. Also, if we normalise the improvement rate (to, e.g., 10\%, arbitrarily chosen for comparison purposes) of all solutions, we can get an estimation of 
how much of the J solution is needed for the same expected improvement (Equations (6) and (7)):

$10 \%$ improvement: $\mathrm{x} \mathrm{ml}$ of J solution $=27 \%$ improvement: $4062.5 \mathrm{~mL}$ of $\mathrm{J}$ solution,

$$
\mathrm{x}=1504.6 \mathrm{~mL} \text { of } \mathrm{J} \text { solution. }
$$

Abo-El-Enein et al. investigated repair potential of a combined approach-sand and bacterial solution (AEE solution). By applying the same calculation method as above, it was estimated that approximately $4006 \mathrm{~mL}$ of repair solution is needed for a $1 \mathrm{~m} \times 0.04 \mathrm{~m} \times$ $0.0003 \mathrm{~m}$ crack, and after adjusting for compression strength improvement (32\% compared to $13 \%$, Figure 4) this gives that relative efficacy is around 300 times lower than the VDB solution. After normalisation to $10 \%$ improvement (Equations (8) and (9)), we get:

10\% improvement: $\mathrm{x} \mathrm{ml}$ of AEE solution $=32 \%$ improvement: $4006 \mathrm{~mL}$ of AEE solution,

$$
\mathrm{x}=1504.6 \mathrm{~mL} \text { of } \mathrm{J} \text { solution. }
$$

Finally, using the same calculation method, we got $3.8 \mathrm{~mL}$ of VDB solution needed for $10 \%$ improvement of compressive strength. The normalised comparison is graphically shown in Figure 7.

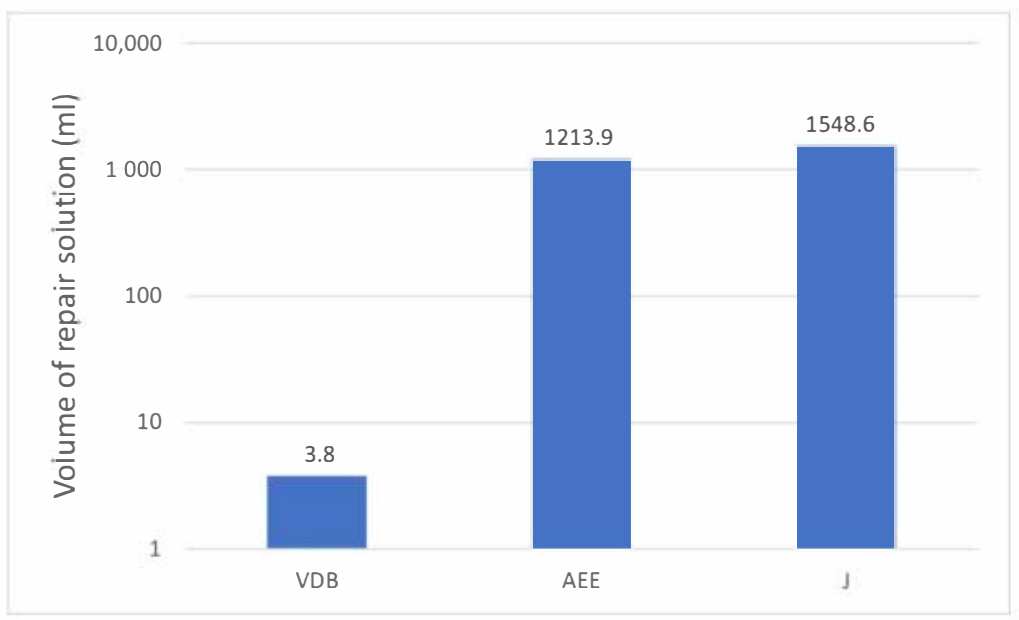

Figure 7. Comparison of required volumes of different external repair solutions for the same expected improvement in compression strength $(10 \%)$.

It was evident that the consumption rates of these solutions are different by at least two orders of magnitude, if not more, which indicated the need for different logistical approaches in eventual real-life application (transport, handling and manipulation costs). It should be noted however that this was only an attempt to put the various solutions available in the literature in the same perspective, and this comparison did not take into consideration various other parameters such as the cost of material, the costs of processing, different application and incubation conditions, different substrates, etc., as these exceeded the scope of this paper. Also, it was assumed that the function between the repair solution volume and the consequential improvement is linear, which needs to be confirmed experimentally.

\subsection{Capillary Water Absorption Reduction}

Sorptivity or capillary suction measurements present a valuable evaluation technique that can give information about the water sealing performance of applied repair solution or self-healing admixtures in building material. There are several techniques developed and standardised for the purpose of determination of capillary action [60-62], but the final 
result is always expressed in mass of water uptake per wetted area per square root of time, and usually the units used are $\mathrm{g} / \mathrm{mm}^{2} / \mathrm{min}^{1 / 2}$. The form of the plotted graph can be used to give a quick general evaluation of possible application of the investigated material, as it shows the performance of the material in unsaturated and saturated conditions.

We introduce a new term—capillary water absorption reduction, defined per Equation (10) as:

$$
\mathrm{W}_{\mathrm{A}} \mathrm{R}=\frac{\left(\mathrm{W}_{\mathrm{b}}-\mathrm{W}_{\mathrm{b}}\right)}{\mathrm{W}_{\mathrm{b}}} \cdot 100 \%
$$

where $W_{a}$ is capillary water absorption of treated samples and $W_{b}$ is capillary water absorption of untreated (blank) samples, which allows us to compare the efficacy of different repair solutions.

The difference in performance and possible application of different repair solutions is evident from the water absorption reduction graphs (Figure 8).

VDB solution, which employed a bacterial suspension based on Sporosarcina pasteurii, had good initial water absorption reduction performance, but after $3 \mathrm{~h}$ it showed a downward trend that eventually resulted in negative performance when the medium became saturated.

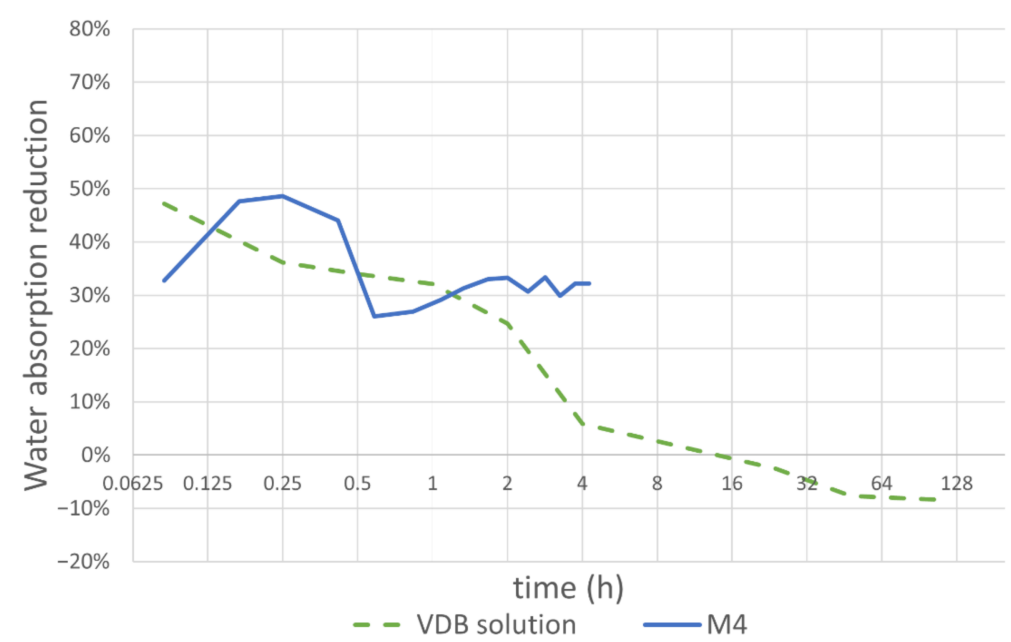

(a)

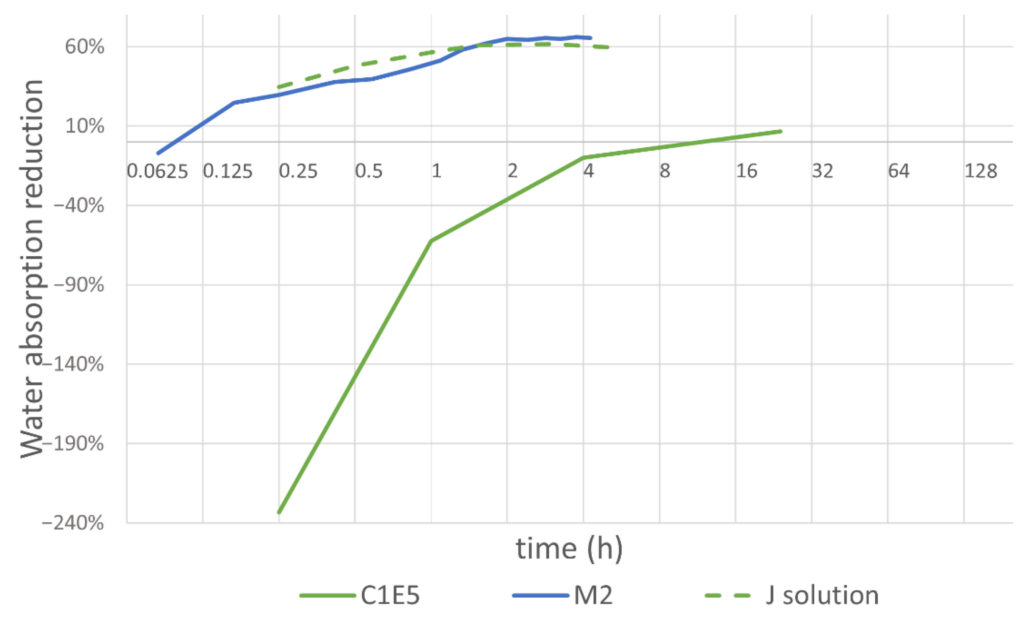

(b)

Figure 8. Cont. 


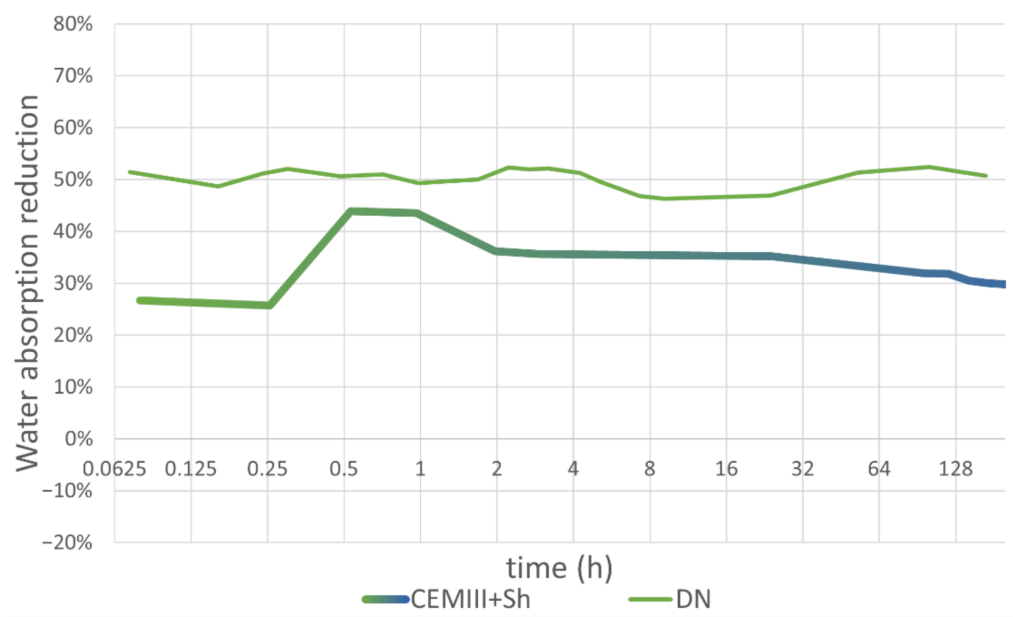

(c)

Figure 8. Comparison of water absorption reductions after treatment with selected repair or selfhealing solutions: (a) "Intermittently wetted" solutions: VDB solution [46], M4 [63]; (b) "Constantly wetted" solutions: C1E5 [64], M2 [63], J solution [43]; (c) "Universal" solutions: CEMIII+Sh [65]; DN [66]. Colour code: green-bio-based; blue-inorganic based; solid line-internal solution; dashed line-external solution.

M2 and M4 are samples that had self-healing admixtures based on novel PVA-coated pellets of different expansive agents added at the mixing phase $(10 \%$ weight replacement of sand). M2 samples had pellets consisting of 50\% MgO and 50\% bentonite, and M4 pellets consisting of $50 \% \mathrm{MgO}$ and $50 \%$ silica fume. M2 showed a positive trend in water absorption reduction throughout the test, while M4 had better initial reduction, which diminished abruptly after $45 \mathrm{~min}$ and remained stable at 30\% until the end of testing $(4 \mathrm{~h})$.

C1E5 mortar sample had 1\% calcium-lactate (of the weight of cement) and $10^{5}$ of S. pasteurii cells $/ \mathrm{mL}$ added to the water in the mixing phase. It was evident that the chosen mix was not optimal for improvement of water sealing performance, as it had negative reduction in capillary absorption of $-233 \%$ in the first 15 min of testing [64], which eventually barely went above $0 \%$. This served as an example how (self-)healing performance must not be evaluated solely based on sealing properties, but instead several testing methods must be applied. Namely, the same mortar mix had very good mechanical properties (compression strength was $21 \%$ higher than control).

J solution had lower performance at the start of the exposure to water, which had a positive trend to about $3 \mathrm{~h}$ of exposure, after which it adopted a downward trend. Unfortunately, the authors limited their experiment to only $5 \mathrm{~h}$, so the long-term capillary action is unknown.

Mohammed et al. [65] obtained very promising results after employing an ironrespiring bacterium Shewanella oneidensis in their concrete mix (CEMIII+Sh), which showed a steady reduction of water absorption throughout the experiment with best results (40\%) between 0.5 and $3.5 \mathrm{~h}$ of exposure to capillary absorption. The reduction then settled at about $25 \%$ without adverse effect observed on the compression strength.

An interesting example is a bio-mortar developed by Erşan et al. [66] containing expanded clay particles and Diaphorobacter nitroreducens bacteria, which exhibited almost constant water absorption reduction of $50 \%$ for the whole duration of the experiment.

In terms of eventual real-life application, the proposed solutions can be roughly divided in three general types: "intermittently wetted" solutions, "constantly wetted" solutions and "universal" solutions. "Intermittently wetted" solutions are those whose absorption characteristics suggest that they would have maximal efficacy in zones occasionally exposed to water, e.g., occasional rain, tidal splash and similar. These agents modify the material in such way that the largest reduction of capillary absorption (compared to non-treated material) happens in the beginning stages of the exposure to water, with less 
efficacy at later stages when the medium becomes saturated. Examples of "intermittently wetted" solutions discussed in this paper are VDB solution and M4 (Figure 7). "Constantly wetted" solutions, on the other hand, show better relative efficacy in later stages of testing, i.e., when they are completely saturated with water. This type of agent is more suitable for areas permanently exposed to water, e.g., submerged zones or areas with frequent rain. C1E5, M2, and J solutions are some examples of "constantly wetted" solutions (Figure 7). Finally, we have "universal" solutions, whose water absorption reduction is more or less constant during the whole testing period and which could potentially be used for both type of exposure (intermittent and constant). Examples would be DN and CEMIII+Sh (Figure 7). For final conclusions about the possible applications of selected healing solutions, other parameters should be included, such as the substrate type, curing conditions and duration, expected crack widths, etc., and this comparison should only serve as a general indicator of potential application.

\section{Conclusions}

This paper presents an attempt to compare data on repair and self-healing solutions for cementitious materials available in the contemporary literature, according to the criteria used in the research conducted by the authors. Given the multi-disciplinary nature of the research field, there are multiple issues, with the results usually being incomparable to one another due to different methodologies of experimental set-up, crack generation, mortar/concrete mixes, curing and testing protocols, etc. Given all these variables, the only way to compare results from different authors was to choose testing methods that were used by the majority of authors and to 'normalise' the results of the repair or self-healing solutions (relative to unassisted recovery processes). In order to evaluate the effects of remediation agents, both mechanical and sealing properties should be taken into account. Therefore, the data obtained by the two most widely used testing methods for these characteristics were presented: compressive strength test and capillary water absorption. Additionally, the consumption rates of different repair solutions were also compared in order to give an insight in their efficacy. It was shown that the rates of consumption needed for the same relative improvements of mechanical strength varied by several orders of magnitude between various solutions, which should be taken into consideration for their eventual application in real life. Capillary water absorption reduction can be an indicator of possible application choices as well, given that different solutions have different capillary action characteristics, which make them more suitable for zones with different wetting patterns (intermittent or constant). Without a standardised protocol for evaluation of efficacy between different solutions and application methods, compressive strength recovery improvement could give an insight in this regard, as it presents an attempt to compare various solutions based on their function as an enhancer of material performance compared to unassisted recovery processes (e.g., autogenic self-healing). Results show that "hybrid" solutions, based on both bio-based and non-bio-based components, whether externally or internally applied, have the potential for the best repair results, synergistically combining their benefits. These techniques, therefore, present a promising path for further research in the field of sustainable infrastructure and building environment in general.

Author Contributions: Conceptualisation, J.M.v.d.B., A.B.; methodology, J.M.v.d.B., A.B., B.M.; investigation, J.M.v.d.B., O.Š., S.V.; resources, A.B., M.R., J.R., S.M.; data curation, J.M.v.d.B., O.Š.; writing-original draft preparation, J.M.v.d.B., A.B.; writing—review and editing, S.V., B.M., J.R.; visualization, J.M.v.d.B., B.M.; supervision, A.B., M.R., J.R., S.M. All authors have read and agreed to the published version of the manuscript.

Funding: This research was funded by COST CA15202 "Self-Healing as Preventive Repair of Concrete Structures (SARCOS)", Royal Society research grant RGS \R1 \191304-Research Grants 2019 Round 1, and the Serbian Ministry of Education, Science and Technological development (Project No. 45103-9/2021-14/200134).

Institutional Review Board Statement: Not applicable. 
Informed Consent Statement: Not applicable.

Data Availability Statement: The data presented in this study are available in cited references and on request from the corresponding authors.

Acknowledgments: This research was supported by COST CA15202 "Self-Healing as Preventive Repair of Concrete Structures (SARCOS)", Royal Society research grant RGS $\backslash$ R1 $\backslash 191304$ - Research Grants 2019 Round 1, and the Serbian Ministry of Education, Science and Technological development (Project No. 451-03-68/2020-14/200134).

Conflicts of Interest: The authors declare no conflict of interest.

\section{References}

1. Sidiq, A.; Gravina, R.; Giustozzi, F. Is concrete healing really efficient? A review. Constr. Build. Mater. 2019, 205, 257-273. [CrossRef]

2. Zhang, W.; Zheng, Q.; Ashour, A.; Han, B. Self-healing cement concrete composites for resilient infrastructures: A review. Compos. Part B Eng. 2020, 189, 107892. [CrossRef]

3. Olivier, J.G.J.; Janssens-Maenhout, G.; Muntean, M.; Peters, J.A.H.W. Trends in Global CO2 Emissions-2016 Report. 2016. Available online: https:/ / edgar.jrc.ec.europa.eu/news_docs/jrc-2016-trends-in-global-co2-emissions-2016-report-103425.pdf (accessed on 11 February 2021).

4. Sidiq, A.; Setunge, S.; Gravina, R.J.; Giustozzi, F. Self-repairing cement mortars with microcapsules: A microstructural evaluation approach. Constr. Build. Mater. 2020, 232, 117239. [CrossRef]

5. Kim, H.; Tae, S.; Ahn, Y.; Yang, J. Scenarios for Life Cycle Studies of Bridge Concrete Structure Maintenance. Sustainability 2020, 12, 9557. [CrossRef]

6. Sangadji, S. Can Self-healing Mechanism Helps Concrete Structures Sustainable? Procedia Eng. 2017, 171, 238-249. [CrossRef]

7. Mengel, L.; Krauss, H.-W.; Lowke, D. Water transport through cracks in plain and reinforced concrete-Influencing factors and open questions. Constr. Build. Mater. 2020, 254, 118990. [CrossRef]

8. $\quad$ BSI. Eurocode 2: Design of Concrete Structures_Part 1: General Rules and Rules For Buildings-(Together with United Kingdom National Application Document); British Standards Institution: London, UK, 1992.

9. ACI Committee 318. Building Code Requirements for Structural Concrete; American Concrete Institute: Farmington Hills, MI, USA, 2014.

10. BSI. Eurocode 2: Design of Concrete Structures_Part 2: Concrete Bridges-Design and Detailing Rules (BS EN 1992-2:2005); British Standards Institution: London, UK, 2005.

11. Li, K.; Li, L. Crack-altered durability properties and performance of structural concretes. Cem. Concr. Res. 2019, 124, 1-11. [CrossRef]

12. Tuutti, K. Corrosion of Steel in Concrete; Swedish Cement and Concrete Research Institute: Stockholm, Sweden, 1982.

13. Käthler, A.C.B.; Angst, U.M.; Wagner, M.; Larsen, C.K.; Elsener, B. Effect of Cracks on Chloride-Induced Corrosion of Steel in Concrete-A Review; Norwegian Public Roads Administration: Oslo, Norway, 2017.

14. Angst, U. Durable Concrete Structures: Cracks \& Corrosion and Corrosion \& Cracks. In Proceedings of the 10th International Conference on Fracture Mechanics of Concrete and Concrete Structures; Pijaudier-Cabot, G., Grassl, P., La Borderie, C., Eds.; International Association for Fracture Mechanics of Concrete and Concrete Structures: Bayonne, France, 2019.

15. De Belie, N.; Gruyaert, E.; Al-Tabbaa, A.; Antonaci, P.; Baera, C.; Bajare, D.; Darquennes, A.; Davies, R.; Ferrara, L.; Jefferson, T.; et al. A Review of Self-Healing Concrete for Damage Management of Structures. Adv. Mater. Interfaces 2018, 5, 1-28. [CrossRef]

16. Reddy, T.C.S.; Ravitheja, A. Macro mechanical properties of self-healing concrete with crystalline admixture under different environments. Ain Shams Eng. J. 2019, 10, 23-32. [CrossRef]

17. Heide, N.T.; Schlangen, E. Selfhealing of early age cracks in concrete. In Proceedings of the First International Conference on Self-Healing Materials, Noordwijk aan Zee, The Netherlands, 18-20 April 2007.

18. Hearn, N. Self-sealing, autogenous healing and continued hydration: What is the difference? Mater. Struct. 1998, 31, 563-567. [CrossRef]

19. Teall, O.R. Crack Closure and Enhanced Autogenous Healing of Structural Concrete Using Shape Memory Polymers; Cardiff University: Cardiff, UK, 2016.

20. Wang, R.; Yu, J.; Gu, S.; He, P.; Han, X.; Liu, Q. Investigation of self-healing capability on surface and internal cracks of cement mortar with ion chelator. Constr. Build. Mater. 2020, 236, 117598. [CrossRef]

21. Li, G.; Liu, S.; Niu, M.; Liu, Q.; Yang, X.; Deng, M. Effect of granulated blast furnace slag on the self-healing capability of mortar incorporating crystalline admixture. Constr. Build. Mater. 2020, 239, 117818. [CrossRef]

22. Stanaszek-Tomal, E. Bacterial Concrete as a Sustainable Building Material? Sustainability 2020, 12, 696. [CrossRef]

23. Nayanthara, P.G.N.; Dassanayake, A.B.N.; Nakashima, K.; Kawasaki, S. Microbial Induced Carbonate Precipitation Using a Native Inland Bacterium for Beach Sand Stabilization in Nearshore Areas. Appl. Sci. 2019, 9, 3201. [CrossRef]

24. Vucetic, S.; Miljevic, B.; Sovljanski, O.; Van Der Bergh, J.M.; Markov, S.; Hirsenberger, H.; Malesevic, M.T.; Ranogajec, J. Functional mortars for conservation of cultural heritage structures. IOP Conf. Ser. Mater. Sci. Eng. 2020, 949, 12091. [CrossRef] 
25. Al-Salloum, Y.; Hadi, S.; Abbas, H.; Almusallam, T.; Moslem, M. Bio-induction and bioremediation of cementitious composites using microbial mineral precipitation-A review. Constr. Build. Mater. 2017, 154, 857-876. [CrossRef]

26. Gomez, M.G.; Anderson, C.M.; Graddy, C.M.R.; DeJong, J.T.; Nelson, D.C.; Ginn, T.R. Large-Scale Comparison of Bioaugmentation and Biostimulation Approaches for Biocementation of Sands. J. Geotech. Geoenviron. Eng. 2017, 143, 04016124. [CrossRef]

27. Sovljanski, O.; Pezo, L.; Tomic, A.; Ranitovic, A.; Cvetkovic, D.; Markov, S. Operating parameter optimization of cell surface hydrophobicity test for ureolytic bacteria. J. Serbian Chem. Soc. 2020, 82. [CrossRef]

28. Pang, H.; Wang, G.; Yang, H.; Wu, H.; Wang, X.; Chen, Y. Identification of Ureolytic Bacteria for Concrete Formation and Antifungal Activity from the Soil with Long-Term Application of Urea Fertilizer. IOP Conf. Ser. Earth Environ. Sci. 2019, 252, 052131. [CrossRef]

29. Andreolli, M.; Lampis, S.; Bernardi, P.; Calò, S.; Vallini, G. Bacteria from black crusts on stone monuments can precipitate CaCO3 allowing the development of a new bio-consolidation protocol for ornamental stone. Int. Biodeterior. Biodegrad. 2020, $153,105031$. [CrossRef]

30. Jimenez-Lopez, C.; Rodriguez-Navarro, C.; Piñar, G.; Carrillo-Rosúa, F.; Rodriguez-Gallego, M.; Gonzalez-Muñoz, M. Consolidation of degraded ornamental porous limestone stone by calcium carbonate precipitation induced by the microbiota inhabiting the stone. Chemosphere 2007, 68, 1929-1936. [CrossRef]

31. Stocks-Fischer, S.; Galinat, J.K.; Bang, S.S. Microbiological precipitation of CaCO3. Soil Biol. Biochem. 1999, 31, $1563-1571$. [CrossRef]

32. Portugal, C.R.M.E.; Fonyo, C.; Machado, C.C.; Meganck, R.; Jarvis, T. Microbiologically Induced Calcite Precipitation biocementation, green alternative for roads-is this the breakthrough? A critical review. J. Clean. Prod. 2020, 262, 121372. [CrossRef]

33. Choi, S.-G.; Wang, K.; Wen, Z.; Chu, J. Mortar crack repair using microbial induced calcite precipitation method. Cem. Concr. Compos. 2017, 83, 209-221. [CrossRef]

34. Manzur, T.; Huq, R.S.; Efaz, I.H.; Afroz, S.; Rahman, F.; Hossain, K. Performance enhancement of brick aggregate concrete using microbiologically induced calcite precipitation. Case Stud. Constr. Mater. 2019, 11, e00248. [CrossRef]

35. Omoregie, A.I.; Ngu, L.H.; Ong, D.E.L.; Nissom, P.M. Low-cost cultivation of Sporosarcina pasteurii strain in food-grade yeast extract medium for microbially induced carbonate precipitation (MICP) application. Biocatal. Agric. Biotechnol. 2019, 17, 247-255. [CrossRef]

36. Wang, Y.; Soga, K.; DeJong, J.T.; Kabla, A.J. Microscale Visualization of Microbial-Induced Calcium Carbonate Precipitation Processes. J. Geotech. Geoenvironmental Eng. 2019, 145, 04019045. [CrossRef]

37. Zhang, J.; Zhao, C.; Zhou, A.; Yang, C.; Zhao, L.; Li, Z. Aragonite formation induced by open cultures of microbial consortia to heal cracks in concrete: Insights into healing mechanisms and crystal polymorphs. Constr. Build. Mater. 2019, $224,815-822$. [CrossRef]

38. Phillips, A.J.; Gerlach, R.; Lauchnor, E.; Mitchell, A.C.; Cunningham, A.B.; Spangler, L. Engineered applications of ureolytic biomineralization: A review. Biofouling 2013, 29, 715-733. [CrossRef] [PubMed]

39. Vijay, K.; Murmu, M.; Deo, S.V. Bacteria based self-healing concrete-A review. Constr. Build. Mater. 2017, 152, 1008-1014. [CrossRef]

40. Jafarnia, M.S.; Saryazdi, M.K.; Moshtaghioun, S.M. Use of bacteria for repairing cracks and improving properties of concrete containing limestone powder and natural zeolite. Constr. Build. Mater. 2020, 242, 118059. [CrossRef]

41. Joshi, S.; Goyal, S.; Mukherjee, A.; Reddy, M.S. Microbial healing of cracks in concrete: A review. J. Ind. Microbiol. Biotechnol. 2017, 44, 1511-1525. [CrossRef]

42. Gupta, S.; Kua, H.W.; Pang, S.D. Healing cement mortar by immobilization of bacteria in biochar: An integrated approach of self-healing and carbon sequestration. Cem. Concr. Compos. 2018, 86, 238-254. [CrossRef]

43. Jongvivatsakul, P.; Janprasit, K.; Nuaklong, P.; Pungrasmi, W.; Likitlersuang, S. Investigation of the crack healing performance in mortar using microbially induced calcium carbonate precipitation (MICP) method. Constr. Build. Mater. 2019, 212, 737-744. [CrossRef]

44. Chunxiang, Q.; Jianyun, W.; Ruixing, W.; Liang, C. Corrosion protection of cement-based building materials by surface deposition of CaCO3 by Bacillus pasteurii. Mater. Sci. Eng. C 2009, 29, 1273-1280. [CrossRef]

45. Kaur, N.P.; Majhi, S.; Dhami, N.K.; Mukherjee, A. Healing fine cracks in concrete with bacterial cement for an advanced non-destructive monitoring. Constr. Build. Mater. 2020, 242, 118151. [CrossRef]

46. Van Der Bergh, J.M.; Miljević, B.; Šovljanski, O.; Vučetić, S.; Markov, S.; Ranogajec, J.; Bras, A. Preliminary approach to bio-based surface healing of structural repair cement mortars. Constr. Build. Mater. 2020, 248, 118557. [CrossRef]

47. Abo-El-Enein, S.; Ali, A.; Talkhan, F.N.; Abdel-Gawwad, H. Utilization of microbial induced calcite precipitation for sand consolidation and mortar crack remediation. HBRC J. 2012, 8, 185-192. [CrossRef]

48. Sánchez, M.; Faria, P.; Ferrara, L.; Horszczaruk, E.; Jonkers, H.; Kwiecień, A.; Mosa, J.; Peled, A.; Pereira, A.; Snoeck, D.; et al. External treatments for the preventive repair of existing constructions: A review. Constr. Build. Mater. 2018, 193, 435-452. [CrossRef]

49. BSI. Products and Systems for the Protection and Repair of Concrete Structures-Definitions, Requirements, Quality Control and Evaluation of Conformity (BS EN 1504-10:2017); British Standards Institution: London, UK, 2017.

50. Shamsuddoha, M.; Hüsken, G.; Schmidt, W.; Kühne, H.-C.; Baeßler, M. Ternary mix design of grout material for structural repair using statistical tools. Constr. Build. Mater. 2018, 189, 170-180. [CrossRef] 
51. Mirza, J.; Saleh, K.; Langevin, M.-A.; Mirza, S.; Bhutta, M.A.R.; Tahir, M.M. Properties of microfine cement grouts at $4^{\circ} \mathrm{C}, 10^{\circ} \mathrm{C}$ and $20^{\circ} \mathrm{C}$. Constr. Build. Mater. 2013, 47, 1145-1153. [CrossRef]

52. Somarathna, H.; Raman, S.; Mohotti, D.; Mutalib, A.; Badri, K. The use of polyurethane for structural and infrastructural engineering applications: A state-of-the-art review. Constr. Build. Mater. 2018, 190, 995-1014. [CrossRef]

53. Issa, C.A.; Debs, P. Experimental study of epoxy repairing of cracks in concrete. Constr. Build. Mater. 2007, 21, 157-163. [CrossRef]

54. Bader, T.; Lackner, R. Acrylic surface treatment applied to architectural High-Performance Concrete (HPC): Identification of potential pitfalls on the way to long-lasting protection. Constr. Build. Mater. 2020, 237, 117415. [CrossRef]

55. Song, X.; Wei, J.; He, T. A method to repair concrete leakage through cracks by synthesizing super-absorbent resin in situ. Constr. Build. Mater. 2009, 23, 386-391. [CrossRef]

56. Shen, L.; Jiang, H.; Wang, T.; Chen, K.; Zhang, H. Performance of silane -based surface treatments for protecting degraded historic concrete. Prog. Org. Coatings 2019, 129, 209-216. [CrossRef]

57. Ferrara, L.; Van Mullem, T.; Alonso, M.C.; Antonaci, P.; Borg, R.P.; Cuenca, E.; Jefferson, A.; Ng, P.-L.; Peled, A.; Roig-Flores, M.; et al. Experimental characterization of the self-healing capacity of cement based materials and its effects on the material performance: A state of the art report by COST Action SARCOS WG2. Constr. Build. Mater. 2018, 167, 115-142. [CrossRef]

58. De Nardi, C.; Bullo, S.; Ferrara, L.; Ronchin, L.; Vavasori, A. Effectiveness of crystalline admixtures and lime/cement coated granules in engineered self-healing capacity of lime mortars. Mater. Struct. 2017, 50, 191. [CrossRef]

59. Khushnood, R.A.; Qureshi, Z.A.; Shaheen, N.; Ali, S. Bio-mineralized self-healing recycled aggregate concrete for sustainable infrastructure. Sci. Total Environ. 2020, 703, 135007. [CrossRef] [PubMed]

60. Rooij, M.; van Tittelboom, K.; Belie, N.; Schlangen, E. Self-Healing Phenomena in Cement-Based Materials: State-of-the-Art Report of RILEM Technical Committee. In State-of-the-Art Report of RILEM Technical Committee 221-SHC: Self-Healing Phenomena in Cement-Based Materials; Springer: Dordrecht, The Netherlands, 2013.

61. BSI. Methods of Test for Mortar for Masonry, Part 11 Determination of Flexural Compressive Strength Hardened Mortar (EN 1015-18:2002); British Standards Institution: London, UK, 2002.

62. ASTM C1585-13. Standard Test Method for Measurement of Rate of Absorption of Water by Hydraulic Cement Concretes; ASTM International: West Conshohocken, PA, USA, 2013; pp. 1-6.

63. AlGhamri, R.; Al-Tabbaa, A. Self-healing of cracks in mortars using novel PVA-coated pellets of different expansive agents. Constr. Build. Mater. 2020, 254, 119254. [CrossRef]

64. Vaezi, M.; Zareei, S.A.; Jahadi, M. Recycled microbial mortar: Effects of bacterial concentration and calcium lactate content. Constr. Build. Mater. 2020, 234, 117349. [CrossRef]

65. Mohammed, H.; Ortoneda-Pedrola, M.; Nakouti, I.; Bras, A. Experimental characterisation of non-encapsulated bio-based concrete with self-healing capacity. Constr. Build. Mater. 2020, 256, 119411. [CrossRef]

66. Erşan, Y.Ç.; Hernandez-Sanabria, E.; Boon, N.; de Belie, N. Enhanced crack closure performance of microbial mortar through nitrate reduction. Cem. Concr. Compos. 2016, 70, 159-170. [CrossRef] 